\title{
Yes to Local Government, No to Participatory \\ Democracy: The Local Governance Reform Dilemma in Trinidad, St. Lucia and St. Vincent
}

\section{Commonwealth Journal of Local Governance}

Issue 3: May 2009

http://epress.lib.uts.edu.au/ojs/index.php/cjlg

\section{Bishnu Ragoonath}

Department of Behavioural Sciences

The University of the West Indies, Trinidad

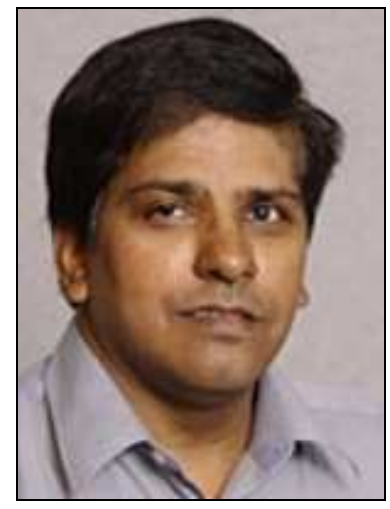

\begin{abstract}
In the Commonwealth Caribbean countries of St. Lucia, St. Vincent and the Grenadines and Trinidad and Tobago, local government reform has been and continues to remain on the agenda. The proposals are all based on the philosophy that there should be elected local government, which in turn should facilitate substantive levels of participatory democracy and citizen involvement. However, whilst there is general acceptance of this philosophy, central governments are seemingly reluctant to implement any reforms that would return power to the people. Citizen involvement and participatory democracy has thus become the bugbear in the process, and has led to the stalling of local government reform in all three countries. With reforms having stalled, one wonders whether the next step will be the dissolution of systems of local government in these states.
\end{abstract}

Key words: Trinidad, Tobago, St Lucia, St Vincent and the Grenadines, participatory democracy, local government, local governance reform 


\section{Introduction}

The Caribbean can today boast of having a long history of local government (Ragoonath 1994, pp. 1-20). As early as 1596, in Trinidad, the Spaniards who had settled on the island established a Cabildo in the island's capital town of St. Joseph. In 1626 and 1655, the British colonists had set up Vestry systems in Barbados and Jamaica respectively. In the case of Guyana, the Dutch initially founded local government systems in the seventeenth century. In creating local governments in their respective colonies, the colonial powers modelled the Caribbean systems along the lines of what existed in the 'mother country' at the time. Subsequent reforms in the Caribbean also followed reforms in the 'mother country.'

Fast tracking to the start of the $20^{\text {th }}$ century, and following the many wars of conquest as well as the trading of colonies, Britain ended up controlling the majority of the Caribbean islands. Local government systems in these colonies were thus reformed or re-established along the lines of the model used 'at home' in Britain. Thus, for instance in Trinidad, at the turn of the century there were three Town/Borough Councils. In 1945 County Councils were established so that the entire country fell under some form of local government. Critical in all of this was that all local government authorities had elected councils, whereby the burgesses elected their representatives and indirectly had a say in the governance of the localities. In St. Vincent, local government was first introduced in 1897 with the Kingstown Town Board, which was also elected. In the 1940s and 1950s several other local government authorities were established utilizing a similar modus operandi as the Kingstown Town Board (LGRC 2005). St. Lucia's local government system was established in 1947 at around the same time that Trinidad and Tobago and St. Vincent were widening the scope and range of local government authorities.

The push to reform and expand local government systems in the Caribbean in the post 1945 era came largely as a result of the recommendations of the West Indian Commission report, under the chairmanship of Lord Moyne (Great Britain 1945). As noted above, the model adopted was in keeping with the tenets of the local government system as existing at that time in Britain. Thus, local government systems in the Caribbean evolved utilizing the mode of a council comprising a majority of elected members, with responsibility for the governance of the locality/community. Many local 
government authorities had some degree of autonomy and revenue raising powers, similar to those, which existed in Britain.

But whereas the British model of local government continued to evolve in the latter half of the $20^{\text {th }}$ century, with the further strengthening of local government councils and in turn the strengthening of participatory democracy, the opposite can be said to be the fate of local government systems in some islands of the Caribbean. In the case of St. Vincent, in 1973 all local authorities were dissolved thus "terminating the involvement of the people on who should represent them and the kind of programs [that the localities were] to embark on." (LGRC 2005) In the case of St. Lucia, some six years later in 1979, "local government elections were suspended and Interim Councils comprising nominated members were appointed to conduct the affairs of Towns and Village Councils." (Ministry of Community Development, Culture, Cooperatives and Local Government 2000) In Trinidad, while the elected systems continued, there were other reforms that sought to further empower the central government rather than local government councils. (Ragoonath 1993, pp. 685-700) The end result is that by the end of the $20^{\text {th }}$ century, whilst there were some remaining systems of local government, the capacity of the citizenry to effectively participate in the 'self-government' of their communities was severely limited. Calls for reforms to local government systems were thus made, and with apparent success, so much so that there now exist Green Papers for local government reforms in St. Lucia and Trinidad and Tobago, while in the case of St. Vincent, a Local Government Reform Commission was established and that Commission has since produced a report suggesting ways for the reintroduction of local government in that country (LGRC 2005).

This paper takes its departure from these recent developments. With a focus on Trinidad and Tobago, St. Lucia and St. Vincent, it seeks to analyse the philosophy of the local government systems in these three states. In focusing on the philosophy, emphasis is placed on the notion of participatory democracy and citizen involvement in community governance. In other words, the paper seeks to assess and analyse the scope of citizen involvement in the governance of their communities, as well as the capacity of local representatives not merely to oversee, but rather to engage actively in the policy making and implementation of policy in the administration of public affairs in their respective 
localities. The extent to which this happens or the extent to which this is proposed in current moves for reform is the primary concern of this paper.

In this regard, this paper will review the historical challenge of engaging and enabling citizen participation in local government issues. Then, using the Green and White Papers on Local Government in St. Lucia and Trinidad, as well as the Local Government Commission Report from St. Vincent, the paper will demonstrate that rather than facing this challenge of inclusiveness and participatory democracy head on, the proposals for reform, as outlined by the governments of these states have shifted focus to the functions and responsibilities of the local authorities - notwithstanding that the citizenry at large wants to have a greater and more significant say in the governance of their communities.

\section{Conceptualising Participation and Governance in Local Government}

In recent times the concept of decentralization has been used as the basis for strengthening systems of local government in many countries. 'Decentralisation' is an umbrella term used to describe four different modes, namely deconcentration, delegation, devolution and divestment (Ragoonath 2004, pp. 9-24; Litvack et al. 1998). All are evident in various combinations in local government systems in the Caribbean. However, in pursuing decentralisation, classical theories on local government have been commonly overlooked or glossed over. This paper takes the position that local government needs to be located in the arena of participatory democracy. Accordingly, it is instructive to revisit the classical theorists, and thereafter analyse the cases from the Caribbean.

Elections facilitate citizen participation in the process of government but may reduce the scope for direct participation and involvement of the citizenry once representatives are elected, since it is now the representative who participates and not the individual citizen. Moreover, it is common to find that representatives, once elected, are not seen again in their electorates until campaigning starts for their re-election. From this perspective, participation in the context of governance must be more than simply voting in an election. Put differently, representative democracy is there to ensure that all interests are considered, but participation beyond the election of representatives allows for greater accountability, and at the same time ensures that service providers are responsive to the users' needs. It is within such a framework that it may be argued local government can 
facilitate greater participation, by promoting continuous participation beyond the 30second act of marking an " $\mathrm{X}$ " on a ballot paper.

Alexis de Tocqueville (De Tocqueville 1954) took the case further by claiming that in order to facilitate democracy to the extent that each and every individual's opinion is considered; the principle of subsidiarity must be brought to the fore. Subsidiarity in this context is taken to mean the decentralization of decision-making, activities and functions to the lowest possible local level of government. For de Tocqueville, such decentralisation also ensured that the potential for a single individual to influence a decision in his or her favour decreases (De Tocqueville 1954). From such a perspective Herman Finer argued that local governments were "safeguards against the tyranny of the wholesale herd." (Finer 1945, p. 4)

Generally, scholars and theorists advance two main arguments for local government, namely 1) Local government provides an opportunity for political participation; and 2) Local government helps to ensure efficient and effective service delivery. Whilst the Utilitarian theorists have placed emphasis on administrative efficiency, the more orthodox theorists advanced the case that local political institutions were essential systems of democratic governance. In positing the concept of democratic governance, the orthodox theorists advocated that local government authorities widened the opportunity for citizen participation, while at the same time enhancing efficiency and effectiveness of local administration. But exactly how is this achieved?

Local government presents the opportunity for ordinary people to be involved in the decisions that affect their lives and their communities by serving as councillors. But it is not only the councillors who are involved. Going back to de Tocqueville, he presented the notion of 'direct democracy' via what today are often referred to as 'Town Hall meetings' (De Tocqueville 1954). Local government thus provided a platform through which individuals can "voice their needs and learn the art of practical politics." (King and Stoker 1996, p. 7) In postulating that participation is to be viewed is being more than simply voting, Dahl argued that it was only through participation was there the spread of power throughout the society (Dahl 1961). Local government can facilitate such spreading of power as it pertains to local issues, where local leaders must be sensitive to the demands of local groups. Of course in suggesting that participation facilitates the 
spread the power, it must be noted that this can only happen if the systems so allow: the legislative framework or the local authority itself can demarcate the extent of participation by local interest groups or citizens themselves.

The question can then be asked: why should local government authorities want to encourage and facilitate citizen participation when they can dilute their own power (that of elected representatives)? In a similar vein, another question to be asked is: what benefit is there to be earned from such participation? J.S. Mill gave the answers to both these questions in his seminal work published 1861, when he postulated that there was a lot to learn about the practice of politics and government (Mill 1861). Citizens, including politicians, will benefit from a mature education in the values required for the establishment and maintenance of a stable democracy, which must be responsive as well as pluralistic. From the perspective of local government, Mill went on to argue that participation by local residents would allow them to utilize their local understanding of

problems and issues in the design and implementation of policies to better meet their requirements. This is the basis of participatory democracy in local government. Participatory democracy seeks to develop the relationship between state, civil society and subject populations. The impact of this would be the enhancement of a sense of political efficacy. The distance between citizens and centres of power would be reduced, with the nurturing of an active and knowledgeable citizenry. Other critical spin-offs would include increased levels of accountability and transparency.

It is from this perspective that this paper highlights the importance of citizen participation in local government. It now turns to an exploration of the experience of local government systems in Caribbean states in facilitating citizen participation.

\section{An Historical Overview of Participation in Caribbean Local Government}

Local government in the Caribbean has seen various forms of citizen participation. At the time of their establishment, all contemporary local government systems were based on citizens voting in elections to select members of council. Beyond the electoral process, several systems facilitated citizen/community consultations on specific issues so as to get greater citizenry involvement in the affairs of the locality. Be that as it may, however, the capacity of Caribbean local government systems for facilitating participatory democracy 
remains largely unfulfilled. Participation at the electoral level, where it exists, is low. Then, with the absence of legislation to enforce accountability by councils and councillors, there is the virtual 'disappearance' of councillors in the period between elections. Communication between the local authorities, councillors and the citizenry is very limited. This section explores these concerns in greater detail.

As was noted above, one sure means of participation is via elections, so that persons can serve as councillors. Here are several considerations here, including the frequency of elections, the number of councils, as well as the number of councillors within councils. Starting with the case of Trinidad, this country has been somewhat fortunate to have had local government elections on a fairly regular basis in the recent past. However, although the legislation calls for elections every 3 years, in the last forty years there have only been 10 elections. In five instances the elections were held at three-year intervals, whereas in the other five instances there have been postponements, occasioned via a simple majority vote in the national Parliament, resulting in two four-year terms (1983 and 1999), a five year term (1987), and even six-year terms (1971 and 2003). It is instructive to note that currently, whilst elections were due in 2006, the central government sought a postponement for one year, until July 2007, claiming the need to reform the system. With the reforms not completed in time for the elections, a Bill was taken to the Parliament seeking the deferral of the election for another year. Then in July 2008, the central government scrapped the reform proposals, which had been considered during the previous two years, and started the process over again. Accordingly, using just the simple majority required in Parliament, it again deferred elections with the promise that the revised process will be completed within a year. Nevertheless, based on the requirements of the reform proposals, as stated in the Green Paper, and which will be discussed in the next section of this paper, it is highly unlikely that the process will be completed by July 2009, and accordingly there is the belief that the elections will again be postponed. In such a context one is left to wonder if the end result of all these postponements will simply be the indefinite suspension of elections as has occurred in St. Lucia, or whether at some stage the central government in Trinidad may simply dissolve the local government system as happened in St. Vincent and the Grenadines.

In the case of St. Vincent and the Grenadines, between the 1950s and until 1970 there were regular elections. In 1973, however, the government dissolved all the local 
government authorities. Interim Commissioners were appointed, with the intention that elections would be held (LGRC 2005). This never happened, and not only were the elected councils dismissed, but the entire local government system in that country was dissolved.

St. Lucia has fared a little better. Here, in 1979 the councils of the ten statutory Town and Village councils were dissolved ${ }^{1}$ but Interim Councils were appointed to conduct the affairs of the councils. Local government thus was retained but without the electoral element. Since then the central government has continued to appoint councils to manage the local authorities. Effectively there has been the retention of a system of local government in St. Lucia. Moreover, it may be noted that within the last year the system has even been expanded with four new local government jurisdictions being created. Be that as it may, however, the fact remains that citizen participation in local government, from an electoral perspective, has been discontinued in St. Lucia as in the case of St. Vincent and the Grenadines.

Returning to the case of Trinidad where, notwithstanding the recent postponements, a system of elections has been retained in principle, attention can now be turned to the level of participation in the democratic system. As noted above, direct participation in local government comes as a result of being a councillor and the capacity to serve in such a position is dependent upon the number of seats available. In this regard, in the 1950s and 1960s there were a mere 72 seats in the local government system (Parliament of Trinidad and Tobago 1968). Between 1968 and 1977 this number was increased to 100 and since then there has been a gradual increase in seats whereby in the last election in 2003 there were 126. Bearing in mind that the system allows for 2 to 4 nominated aldermen in each council, another 31 citizens are added, thus resulting in 157 citizens being directly involved in the process after an election.

In measuring the extent of participation in the electoral process it may be instructive to also consider the number of candidates as well as the political parties contesting the elections. With respect to the political parties, in Trinidad and Tobago there are two primary political parties, each representative of an ethnic (racial) bloc. Accordingly, in local government elections, it is basically these two parties contesting the elections, with

\footnotetext{
${ }^{1}$ This was done under the Local Councils Dissolution Orders, 1979
} 
the rare entry of independent candidates or community-based candidates. Thus, in 1959 when there were only 72 seats, 174 candidates contested the elections (Parliament of Trinidad and Tobago 1996). This number was to rise to 229 in 1968, when the number of seats was increased to 100 , but in 2003 , a mere 253 persons contested the 126 seats (Parliament of Trinidad and Tobago 2003). Participation from this perspective is not very high.

But participation can also be measured in terms of that of the wider citizenry in the voting process. In the last five local government elections the average voter turnout was $40.25 \%$. While this figure can be described as low, it is much higher than the turnout at the previous five local government elections. In the elections between 1968 and 1983 the average turnout at the polls was a mere $27.35 \%$. Clearly there has been a significant increase in voter participation in local government elections. Whether this trend will continue, one can only wait and see, but if this change is accepted as real, then clearly more and more citizens are taking the opportunity to participate and this is a good sign for participatory democracy.

Against this backdrop, attention will now be turned to an analysis of current reform proposals and their capacity to promote participatory democracy within a context of local governance. As already noted, local government elections are conducted only in one of the countries under review, and even in this instance participation levels were relatively low. Accordingly many persons, including government officials, have spoken of a crisis in participatory democracy not only in these three countries but also in the wider Commonwealth Caribbean. Bearing this in mind, one would have expected that any reforms to local government systems in the region would pay critical attention to promoting and facilitating higher levels of citizen participation. Unfortunately, however, whilst the official documents and statements speak to the need for increased citizen participation, the terms used seem to be weak and ambiguous. Moreover, statements from the Prime Ministers of both Trinidad and Tobago and St. Vincent and the Grenadines seem to be backtracking rather than going forward in facilitating greater participatory democracy (Manning 2008, p. 791; OAS, pp. 6-7). The next section of this paper deals with these mixed signals. 


\section{Assessment of Current Proposals for Reform}

The shortcomings in the local government systems of the Caribbean have long been recognized. In an attempt to resolve some of these challenges, there have been proposals for reform to the local government systems in both St. Lucia and Trinidad and Tobago. In the case of St. Lucia a Green Paper was developed as far back as 2000. In Trinidad and Tobago there was a Green Paper in 2004, which was followed by a White paper in 2006, and a new Green Paper in 2008. Clearly, local government reform has been uppermost in the minds of the government and people of Trinidad and Tobago. The question that arises is: to what extent will proposed reforms facilitate participatory democracy? This section will seek to assess this first by contrasting the official reform proposals with the policy positions that have been stated or adopted by the current central governments Thus, for instance, in the case of Trinidad and Tobago statements made by the Prime Minister are particularly relevant to understanding the policy perspective. Similarly, statements made by the Prime Minister of St. Vincent and the Grenadines can also be used to assess the state of affairs in the reintroduction of local government in that country, and the level to which participatory democracy will be applied.

\section{St Lucia}

Some twenty years after the suspension of elected local government in St. Lucia, the central government employed a consultant to undertake a review of local government reform on the island. The expectation was that the consultant would develop a plan that should "set out the steps required to reintroduce local government elections by 1999." (Armstrong 1999, p. 4) This objective was in keeping, first of all, with the St. Lucia Labour Party 1997 Election Manifesto pledge to deepen the structures of democracy in the island. After winning the elections, the government adopted a policy position that suggested local government in St. Lucia should be “... a highly autonomous, democratic community institution that is: (a) accountable to the community; (b) responsive to local needs and demands; (c) provides a wide range of public services to citizens within the locality; $(d)$ is an active partner with central Government in promoting balanced socioeconomic development and poverty eradication; and (e) contributes to the enhancement of the quality of life and the economic, political, social, cultural and spiritual well-being of the citizenry." (Ministry of Community Development, Culture, Cooperatives and Local Government 2000) 
However, while the consultant did submit a report in September 1999, the 'implementation plan' did not set a timetable for elections. To be sure the report recommended "the drafting of a Green Paper on Local Government Reform for wide circulation, public review and comment leading to the development of a White Paper." (Armstrong 1999, p. 123) This Green Paper was prepared in 2000, but notwithstanding reviews and consultations a White Paper has never been developed.

Before commenting on the failure to advance the process via the development of a White Paper, it can be noted that a number of references to participatory democracy are to be found in the Green Paper. Several recommendations in the Green Paper deal with the relationship between local government authorities and the citizenry. One critical recommendation in this regard proposes the resumption of elected local government, with a term of three years. Moreover, electors would have the right to recall elected members. These recommendations thus seek to empower the electorate. But the St. Lucian 2000 Green Paper went further in suggesting greater citizen participation in local government. There is a recommendation for the local authorities to be required by law to hold public meetings with citizens in the communities that they serve, and that citizens and/or community organizations be allowed to propose items for inclusion on the agenda of such meetings. Also, there is provision for the establishment of an assembly of community organizations that meets regularly to provide general policy guidance to the local authorities and to air issues of concern. With regard to planning, the Green Paper spoke of the need for participatory planning policies and arrangements to be established at all relevant levels. Furthermore, there is a recommendation for the establishment of a tier of advisory committees within the local authority, which should include knowledgeable and competent members of a community. Citizen involvement via participatory democracy was thus a key thrust in the proposals as outlined in the St Lucia Green Paper.

However, whilst the recommendations for local government reform for St. Lucia can be described as far reaching, the process stalled almost immediately after the release of the Green Paper. In the ruling party's 2001 election manifesto, it was stated that the government had "studied the Green Paper", and it made a pledge to establish "local government elections machinery." At the same time the manifesto spoke of "modernizing the structures of local government administration" with the hope to 
"decentralize and devolve power to the local government authorities." (Saint Lucia Labour Party 2001) Be that as it may, on winning re-election the government took no steps in this regard. Whilst there has been no official explanation for not taking the process forward, speculation is rife that the recommendations facilitated too much devolution, which the central government was not willing to entertain.

In December 2006, there was a change in the central government in St. Lucia. The new administration has once more placed local government reform on the agenda. Accordingly, there has been the widening of local government noted earlier and four new local government authorities have been established. But these authorities operate under the same system as other ten, that is, with nominated councils. The central government has also set up a Task Force for the Reform of Local Government, which has within its terms of reference the task of recommending measures and an implementation plan for a system of elected local government. We can only wait for those recommendations and then assess the way forward.

\section{Trinidad and Tobago}

Like St. Lucia, in the case of Trinidad and Tobago there is also a Green Paper, issued in April 2008. However, this paper speaks to the 'Roles and Responsibilities of Local Government Bodies'. When it was first presented, it was noted that this is "a Green Paper that does not deal with local government reform. It deals only with the responsibilities of local government." (Manning 2008, p. 791) To this end it was suggested that following a round of consultations, other elements of local government reform will be formulated. Accordingly fifteen consultations were held and the country now awaits the next step in the reform process. According to the Green Paper, there is supposed to be a White Paper, followed by the drafting of a Bill and taking it through Parliament for passage, proclamation and implementation (Ministry of Local Government 2008, p. 9). But there remains some scepticism as to whether the way forward as outlined in the Green Paper will be followed, particularly in light of the fact that the process, which started in 2008, was but a repeat of a similar process started in 2004. As mentioned above, in the earlier case a draft White Paper was developed and taken to Parliament in 2006. However that was as far as that process went, for the White Paper was shortly thereafter taken off the agenda, only to be followed two years later by the new Green Paper. 
Notwithstanding the feeling of déjà $v u$, from the perspective of participatory democracy and citizen involvement in local decision-making, the two Green Papers and the White Paper leave a lot to be desired. As already noted, the 2008 Green Paper had a focus primarily on roles and responsibilities. In fact the only references in this Green Paper to participatory democracy are to be found in a proposed Mission Statement and a diagram illustrating Shared Values. As to the earlier 2004 Green Paper and the 2006 White Paper, whilst the emphases were on the structures and operations of local government, there were some references to community participation. In the majority of such instances, what was said could best be summarized in the statement made under the heading of Policy Objectives: Community Development and Citizen Participation, namely "establish mechanism that will encourage and promote community involvement and participation." (Ministry of Local Government 2006, p. 24) Since no specifics were mentioned in relation to mechanisms to facilitate participation and involvement, one is left to wonder whether participation was to be limited to voting. In this regard the 2006 White Paper made a clear statement, specifically:

"This system of Local Government facilitates political liberty, since it gives people a sense of empowerment over their environment, and essentially allows them an active role in the decision making processes in the local communities. Our citizens are of the view that they are exercising democracy when they are allowed to elect officials whom they know can preside over their community.",

The lack of attention in the two Green Papers and the White Paper to the issue of participatory democracy can be explained by a policy position on decentralization declared repeatedly by the Prime Minister. Contributing to the parliamentary debate on the 2006 White Paper, the Prime Minister said:

"Under this system the Central Government will be essentially the policy making body, whilst Local Government will be the principal executing arm of the State ....The decentralization of functions and responsibilities to Local Government bodies, rather that the devolution of power, is therefore being advocated as the core of our model of Local Government Reform. In our view, the devolution of authority which involves the decentralization of policy decision making can lead to the fragmentation of the unitary state.” (Manning 2006, p. 376)

\footnotetext{
${ }^{2}$ Ibid.
} 
In maintaining this position, in his contribution to the Parliamentary debate on the second Green Paper, the Prime Minister enunciated that his party would not support devolution in terms of decentralization of the policy making function. In this instance he said: "the PNM is afraid of devolution." (Manning 2008, p. 797) The focus of the 2008 Green Paper on roles and responsibilities of local government bodies is therefore in keeping with the philosophy that there will be no devolution of policy-making powers to local government bodies, but rather they are to operate as the 'agents of the central government' and nothing more. This point was further underscored in the closing statements by the Prime Minister in his contribution to the debate on the 2008 Green Paper. Notwithstanding that he had earlier said that this 2008 Green Paper was not a Green Paper on local government reform, he ended his contribution on a note that his administration was considering the reduction of the number of local government authorities from fourteen to twelve. Whilst he gave no rationale for this proposal, he did indicate that: "we are looking at the total administration of the state." ${ }^{3}$

In such a state of affairs, one is left to wonder as to the real direction of local government reform in Trinidad and Tobago. While lip service is being paid with respect to empowering local government, the statements from the Prime Minister seem to be headed in the direction of the diminution if not the emasculation of local government. Moreover, if all policy is centralized and local government authorities are merely the executing agency for the central government, without any power to make policy decisions, questions about citizen participation in local government become essentially rhetorical.

\section{St. Vincent and the Grenadines}

The primacy of the Prime Minister in determining the fate of local government reform is repeated in the case of St. Vincent and the Grenadines. Further to a debate in the Parliament, a resolution was passed on 12 March, 2002 to set up a "Commission to inquire publicly into and report upon the most appropriate forms of local government for St. Vincent and the Grenadines with a view to establishing genuine, democratic local government for St. Vincent and the Grenadines within twelve months of the passage of this resolution." (LGRC 2005) In passing this motion, the Ralph Gonsalves

\footnotetext{
${ }^{3}$ Ibid. p. 800.
} 
administration had kept an election promise to initiate a process to reintroduce elected local government. However, whilst the motion on the Parliamentary Order Paper spoke of the need for "genuine, democratic Local Government," the government and more so the Prime Minister seemed to have had a change of heart even whilst the motion was being debated. To be sure, the Prime Minister had earlier expressed a concern that elections in local government would likely increase the level of 'political tribalism' within the society and thus he wondered whether this was the way to go. ${ }^{4}$ With such a mindset, the Prime Minister went on to develop a model, which would seemingly avoid the 'partisan political divisiveness' as may arise from local government elections. In addressing a conference on Local Governance in Small States in May 2003, Prime Minister Gonsalves advanced the thesis that local government authorities in the hands of a political party other than that in central government are potentially divisive (OAS 2003, pp. 6-7). He then suggested a formula whereby the majority party in the Parliament will nominate 7 representatives on a local council, while the minority party will nominate 2 representatives. Civil society organizations will have 4 nominees. With such a formula there would be no need to have separate local government elections.

With the Prime Minister's predisposition to a particular local government system well known, a year later, and two years after the motion was passed in the Parliament, the Local Government Reform Commission was appointed in April 2004. The Commission pursued its mandate and submitted a report in November 2005. A critical recommendation of this report was that "with the exception of Civil Society organizations, membership to the local government Authorities should be through an election process." (LGRC 2005, p. 15) This recommendation thus went against the model proposed by the Prime Minister. Six months after the submission of the Commission's report, and at a joint meeting of the Caribbean Forum of Local Government Ministers and the Caribbean Association of Local Government Authorities, the Prime Minister suggested to the Commission's chairman that since the Commission's report had not yet been sent to the Governor General and as such was not yet formally accepted, there was still time to revisit the findings and review the recommendations. Without any such review forthcoming, the status of the report remains in limbo. Whilst the ministry with responsibility had printed several thousand copies, these have not yet been circulated to

\footnotetext{
${ }^{4}$ This was during an interview with the author in March 2001.
} 
invite comment on the report. In fact there can be no such dissemination of the report until the government formally accepts it, and this does not seem to be happening.

This failure to advance the process, via the 'non-acceptance' of the Local Government Reform Commission's Report, has now placed the reintroduction of democratic local government in St. Vincent and the Grenadines on hold. Notwithstanding that the report reflects the views of the wider populace; it is the primacy of the position of Prime Minister which seems to have won out. This does not speak well for participatory democracy and citizen involvement in local governance for St. Vincent and the Grenadines, but is the reality of Caribbean politics.

The Caribbean reality can therefore be summarized as one where a dilemma exists, for whilst, in principle, central governments are supportive of local government systems, they are seemingly opposed to have local government as a mode of dispersing and diffusing power. In this context the real problem is to find a model that can facilitate local government but at the same time allow central government to maintain and even further consolidate power within the polity. Only with the resolution of this political dilemma can the cause of local government be pursued.

\section{Whither Local Governance via Local Government?}

The dilemma being faced by the governments of Trinidad and Tobago, St. Vincent and the Grenadines, and St. Lucia is not one that is peculiar to these societies. It is a common debate in many small countries and more so in those that are plural societies as well as those states that have very limited resources.

With regard to the latter concern, in an attempt by the central government to inflate its revenue base, all income is collected and placed in the consolidated fund, from which expenditures are made directly. In many instances this is a necessary pre-requisite to demonstrate, particularly to international lending agencies, the capacity of the state to raise revenues and control expenditures. In such circumstances, there is little chance for a local government authority to have any degree of financial self-sufficiency or autonomy. Local government authority will only be allowed to act simply as an agent of the central government, whereupon there is only bureaucratic decentralization or deconcentration, and the issue of devolution does not arise. 
While this scenario can be used to explain the reluctance to push local government forward in St. Lucia and St. Vincent, it does not apply to Trinidad and Tobago, where there is already a level of devolution existing via the Tobago House of Assembly, which is accorded a stipulated share of the national budget. And in the cases of St. Lucia and St. Vincent it may be instructive to note that in both states the central government could continue to collect rates and taxes and devise a mechanism for transfers to the local authorities, as currently occurs in Trinidad. Effectively, the financial issue, while remaining a challenge, can be overcome with innovative programming.

Turning to the issue of the plural society, the theory here speaks to the fact that different ethnic groups may live side by side in a society, but there is little or no assimilation, particularly in terms of culture and politics (Smith 1965). Accordingly, there is a struggle for political power, and such power when held by one group is not shared with the other groups. In such a context, some local government theorists have postulated that local government is a good mechanism for the sharing of power through the use of a pluralist system of democracy. The pluralist theory of democracy, as opposed to problematic view of plural societies, seeks to spread power throughout the society so that governments must respond to the demands of the many interests involved (Chandler 2001, p. 10). Thus a critical challenge for the governments in the three countries under review is how to apply the pluralist theory of democracy within the framework of plural societies. This challenge is most evident in Trinidad where, as noted above, there are two ethnic blocs, with near equal strength, and where the struggle for political power takes place between two parties representing those two blocs. Results in recent national elections have seen parties taking power with very slim majorities, and in one instance there was a tie. Against this backdrop the issue of power sharing came to the fore. Accordingly, in a speech to the Parliament in 2006, the Prime Minister had noted that the reform of the local government system could facilitate: "an arrangement for the sharing of power between Central and Local Government in Trinidad and Tobago." (Manning 2006, p. 376) But whereas the Prime Minister invoked the notion of power sharing, his prescription fell short of that and could more appropriately be described as bureaucratic decentralization, when he further explained that: "the Central Government will be essentially the policy making body, whilst Local Government will be the principal 
executing arm of the State." Whilst such a stance serves to share authority with local governments, particularly so where the opposition party controlled approximately half of all the local government authorities, power would still be concentrated in the hands of the central government. The pluralist theory of democracy is not therefore fully invoked in the Prime Minister's proposal.

But whereas the Trinidad and Tobago Prime Minister, conscious of the ethnic/political divide within the country, proposed at least some sharing of authority with local representatives to oversee the execution of government policy in their respective communities, the Prime Minister of St. Vincent and the Grenadines, also cognizant of the political divide in his country, closed the door on diffusing power at all. In the case of St. Vincent and the Grenadines, there is no ethnic or ideological divide, except that the citizenry divide their support between the two major political parties. It is in this context that the argument was made that in an effort to stymie any further deepening of the "partisan political divisiveness" (OAS 2003, pp. 6-7) local government authorities should be appointed, rather than elected, and further that the party in control of the central government should have a majority in all local government authorities. Pluralist democracy is thus not to be incorporated within the proposed system of local government in St. Vincent and the Grenadines if the Prime Minister is to have his way.

Given such thinking, serious concerns remain as to whether foreseeable local government reform in the Caribbean is likely to ensure inclusiveness and true participatory democracy, whereby groups of people or political parties in opposition to the central government would have some genuine capacity to influence policy as it affects their community and their local environment. Citizen involvement and participatory democracy remain elusive tenets in local government in these Caribbean states.

\section{References}

Armstrong, A 1999, Final Report of the Consultancy on Local Government Reform in St. Lucia, Aubrey Armstrong and Associates, Castries, p. 4.

Chandler, J.A. 2001, Local Government Today, Manchester University Press, Manchester, p. 10.

\footnotetext{
${ }^{5}$ Ibid.
} 
Dahl, R 1961, Who Governs, Yale University Press, New Haven.

Finer, H 1945, English Local Government, Methuen, London, p. 4.

Great Britain 1945, West India Royal Commission Report, Lord Moyne, Chairman, H.M.S.O., London.

King and Stoker 1996, Rethinking Local Democracy, Macmillan, London, p. 7.

Litvack et al 1998, Rethinking Decentralization in Developing Countries, World Bank, Washington, DC.

Local Governance Resource Center (LGRC) 2005, Report to the Governor General, Local Government Reform Commission, Kingstown.

Manning P 2006, Statement made on Local Government Reform in Hansard of the House of Representatives on May 26, 2006, p.376.

Manning P 2008, Hansard of the House of Representatives, Trinidad and Tobago, July 7, 2008 in the Municipal Corporation Amendment Bill, pp. 791 - 797.

Mill J.S 1993, 'Considerations on Representative Government' in Williams, G (ed.) Utilitarianism; On Liberty; Considerations on Representative Government, J.M. Dent, London.

Ministry of Community Development, Culture, Cooperatives and Local Government 2000, Green paper on Local Government Reform, MoCDCCLG, Castries.

Ministry of Local Government 2008, A Green Paper on Local Government Reform: Roles and Responsibilities of Local Government Bodies, Ministry of Local Government, Port of Spain, p.9.

Ministry of Local Government 2006, Draft White Paper on Local Government Reform, 2006 Ministry of Local Government, Port of Spain, p. 24.

Organisation of American States (OAS) 2003, 'A Proposal for Local government in St Vincent and the Grenadines' in Local Governance in Small States: Issues, Experiences, Options Washington, OAS, DC, pp. 6-7.

Parliament of Trinidad and Tobago 1968, Report of the Elections and Boundaries Commission on the Local Government Elections 1968, Government Printery, Port-of-Spain.

Parliament of Trinidad and Tobago 1996, Report of the Elections and Boundaries Commission on the Local Government Elections Held on Monday 24 June 1996, Government Printery, Port-of-Spain.

Ragoonath, B 1994, 'Decentralization via Local Government in the Commonwealth Caribbean', Latin American Studies. No. 13, pp. 1-20.

Ragoonath B. 2004, "Local Government Decentralization: A perspective in Caribbean Adaptations and Practices" in Patricia Persaud (ed.) Decentralization and Local Government in the Caribbean, National Democratic Institute for International Affairs, Washington, DC, p. 9-24. 
Ragoonath, B. 1993, 'Shifting Nature of Decentralization: A review of the Evolution of Local Government in Trinidad and Tobago' in Indian Journal of Public Administration, Vol XXXIX, No. 4, pp. 685-700.

Smith, M.G 1965, The Plural Society in the British West Indies, University of California Press, California.

Saint Lucia Labour Party 2001, Manifesto 2001- Our Vision for Saint Lucia: Elections 2001, Saint Lucia Labour Party, Castries. 